\title{
Insulin-like Growth Factor System and Aging
}

Ping Li, Xue-feng Sun, Guang-yan Cai and Xiang-mei Chen ${ }^{*}$

Department of Nephrology, State Key Laboratory of Kidney Disease 2011DAV00088, Chinese PLA General Hospital, Beijing 100853, China

*Corresponding author: Xiang-mei Chen, Department of Nephrology, State Key Laboratory of Kidney Disease, 2011DAV00088, National Clinical Research Center for Kidney Disease, 2013BAI09B05, Chinese PLA General Hospital, Fuxing Road 28, Beijing 100853, PR China, Tel: 86-10-66935462; Fax: 86-10-68130297; E-mail: xmchen301@126.com

Received date: February 06, 2017; Accepted date: February 20, 2017; Published date: February 24, 2017

Copyright: (c) $2017 \mathrm{Li} \mathrm{P}$, et al. This is an open-access article distributed under the terms of the Creative Commons Attribution License, which permits unrestricted use, distribution, and reproduction in any medium, provided the original author and source are credited.

\begin{abstract}
IGF (insulin-like growth factor, IGF) system is composed of three ligands (insulin, IGF-1, IGF-2), three cell surface binding receptors (Ins $\mathrm{R}, \mathrm{IGF}-1 \mathrm{R}, \mathrm{IGF}-2 \mathrm{R}$ ), and Insulin-like growth factor binding proteins (IGF binding proteins, IGFBPS) and IGFBP protease. Delaying aging and exploring the molecular mechanism of aging have always been important research topics. IGF system plays an important role in the life processes by binding with the receptor or activating multiple intracellular signaling cascades. The researches have showed IGF system plays an important role in regulating signal pathways about senescence and aging related diseases such as cardiovascular disease, osteoporosis and vertebral aging.
\end{abstract}

Keywords: IGF-1; Aging; IGFBPs; IGF receptor; Age related diseases

\section{Introduction}

Aging is a common and gradually decreasing process of the function of various organs in the body. Many physiological factors play an important role in aging, one of which is the growth factor Insulinlike (IGF) system. The researches show that local inhibition of signal pathway mediated by insulin like growth factor (Insulin-like growth factors, IGFs) lead to an increase in invertebrate and vertebrate model organisms, which may delay the aging [1]. The study of Caenorhabditis elegans for the first time found that the inhibition of signaling pathway of DAF-2 (encoding insulin-like growth factor-1 receptor,IGF-1R) could increase the lifespan [2-4]. By target mutation, the gene study encoding the invertebrate life has made significant progress, and the research elucidates the inhibition of signal pathway of insulin or insulin-like growth factor-1 can significantly increase the lifespan [5] In fruit flies, yeast and mammals, insulin like signaling cascade, similarly to the DAF-2 signaling pathway, can increase the lifespan by altering the IGF-1 signal pathway. There are a large number of results show that the IGF system plays a significant role in the aging process [6-8].

\section{The Over Review of Insulin Like Growth Factor System}

Insulin like growth factor is a kind of natural growth hormone, which plays an important role in growth and development of the body. The IGF family consists of insulin (Insulin, Ins) and two factors like insulin, IGF-1 and IGF-2. These factors regulate cell function by binding to specific cell surface receptors (Ins RIGF-1RIGF-2R) or activating a variety of intracellular signaling cascades which is regulated by 6 soluble IGF binding proteins (Insulin-like growth factor binding proteins, IGFBPs) and associated protein (IGFBP related proteins, IGFBP-rPs). These IGFBP-rPs are similar to IGFBPs in structure, but the capacity binding with IGFs is lower.

At present, IGFBP-rPs are classified to IGFBPs in many researches, such as IGFBP-rP1 also known as IGFBP7 [9-11]. Former researches suggested that the IGF system was composed of three ligands (Insulin,
IGF-1, IGF-2), three receptors (IGF-1R, Ins R, IGF-2R), 6 IGF binding proteins (IGFBP1-6). With further research, the current research suggests that the IGF system, in addition to the above ligands and receptors, also includes IGFBPs (IGFBP1-6, IGFBP-rP1-10) and IGFBP protease [11].

\section{IGF family}

The first member of the IGF family to be found is insulin, which plays an important role in glucose metabolism and its amount or function decreasing is the main cause of diabetes. IGF-1 and IGF-2 are known as insulin-like ("insulin-like") growth factors because they can stimulate the cells and muscles to absorb glucose, and the homology with insulin reach $50 \%[12,13]$.

The IGFs in the circulation is prevented to be degraded by the formation of complex compounds with high affinity IGFBPs [14]. In tissue, IGFBPs can inhibit the binding of IGFs with the corresponding receptor, because the binding affinity of IGFBPs and IGFs is higher than that of the receptor and IGFs. In some cases, IGFBPs act as a reservoir for releasing IGF ligands slowly to enhance the role of IGF in the microenvironment. In addition, some IGFBPs can affect cells not depending on the IGFs. IGFBPs does not combine with insulin, therefore does not interfere with binding between insulin and insulin receptor (Ins R).

\section{Insulin receptor and IGF receptor}

IGF-1R and IGF-2R are the main receptors of the IGF system, which are two transmembrane glycoproteins completely different in structure and function [15-21]. IGF-1R is tetramer composed of two identical alpha-subunits and two identical beta-subunits, which is similar to the insulin receptor (Insulin receptor, IR) in structure [18,19,22].

Although the affinity is weaker than the preferential binding ligands, IGFs and Insulin can bind crossly to their receptors (Figure 1) [23-25]. IGF-2R is monomer, and no correlation with IR and IGF-1R in function, the receptor for extracellular region has three ligand binding domain, one combine with IGF-2, one combine with mannose 6- 
Page 2 of 5

phosphate (M6P) and another combine with inactive transforming growth factor, transforming growth factor (transforming growth factor - TGF- $[26,27]$. The complex combined with IGF-2 can combine with TGF- beta, and activate the TGF- beta [28]. The only function of IGF-2R in the IGF system is to capture the cycle of IGF-2, so that the IGF-2 is hydrolyzed to soluble fragments, promoting its degradation $[29,30]$.

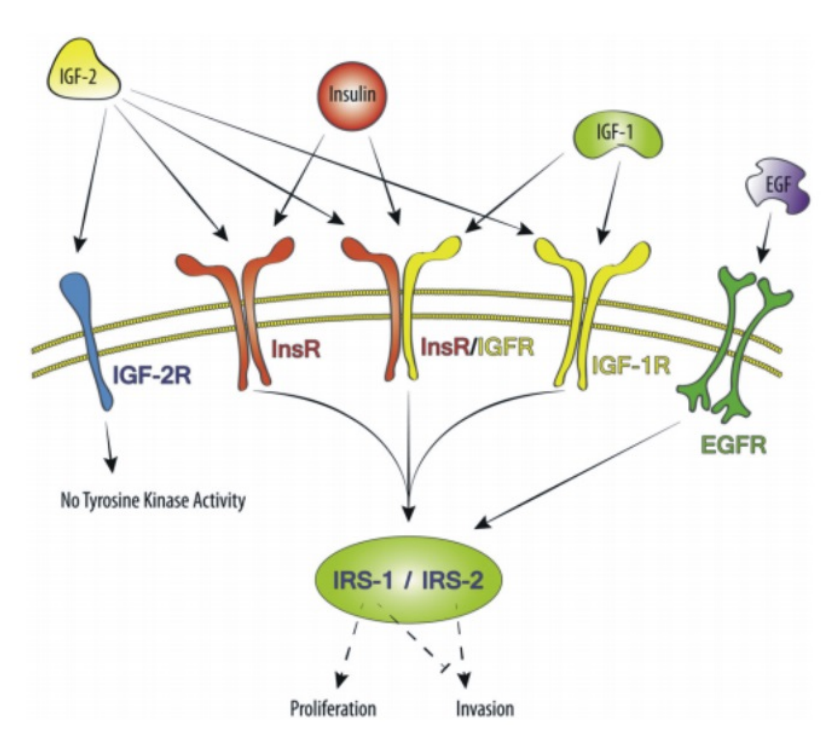

Figure 1: IGFs and Insulin binding.

Cell signalling post-receptor consists of phosphorylation of insulin receptor substrate-1 (insulin receptor substrate, IRS) family protein and activation of phosphatidylinositol-3 (phosphatidylinositol-3, PI-3), and mitogen activated protein kinase [15]. Activation of IRs induce the activation of intracellular Raf/Mek/ErkRas/ and PI3K signaling pathway, the former mainly mediate mitosis, and PI3K pathway mediate metabolism and cell growth effect through Akt [31].

\section{IGFBPs family}

IGFBPs and IGFBP protease are important components of IGF system. According to the affinity with IGFBPs, IGFs are divided into two groups: IGF high affinity binding protein (IGFBP1-6); IGF low affinity IGFBP associated protein (IGFBP-rP1-10) [32]. IGFBPs regulate the biological activity by combining with IGFs and its receptor, and play an important role in cell growth, division, differentiation, apoptosis, aging and other processes. Some functions rely on IGF signal, and some are not. IGFBP protease belongs to the proteases family, which specific to IGFBPs, regulated by IGFBPs, and ultimately regulate the biological activity and downstream signal transduction of IGFs [14].

\section{Igf System And Cellular Senescence}

Cell senescence is the cell cycle arrest, which is not reversible, and is closely related to the aging of the body. A large number of studies have indicated that increased IGF signal can promote cell division, survival and development of cancer cells, and the inhibition of IGF signaling is thought to be able to delay aging. The molecular mechanism of IGF signaling in the regulation of aging, and whether IGF regulates cellular senescence are still poorly understood.

\section{IGF-1 and molecular mechanisms of aging}

Tran D's study found that continuous IGF-1 treatment can inhibit the biological activity of SIRT1, which makes the p53 acetylation and increase of p53 stability and biological activity, and further lead to immature cell aging. In addition, the inhibition of SIRT1 expression or p53 inhibited the senescence of immature cells induced by IGF-1. The results suggest that $\mathrm{p} 53$ acts as a link molecule that mediates cell proliferation and senescence induced by IGF-1, suggest that IGF-1SIRT1-p53 is a possible molecular link signaling in cell senescence and maturation [33].

By monitoring the lifespan of mice which lacked the IRS1 and IRS2, the female IRS1 -/- mice lived longer. IRS1 -/- mice exhibit resistance effect for a series of age sensitive physiological indexes including skin, bone, immunity and motion dysfunction [34].

\section{IGFBPs and aging}

Recent studies have found a molecular group that is secreted by aging cells and is proposed to be called "senescence-associated secretory phenotype" (SASP). These secrete factors can regulate the aging reaction, which represents a dangerous signal that represents the normal neighboring cells to the aging, can enhance the damage to cell aging. It is suggested that the IGFBPs family is closely related to SASP [35]. In addition, IGFBPs were confirmed to have the role of regulation of cell aging a variety of cells, speculated that IGFBPs may be used as a biological indicator of aging.

\section{IGFBP2}

In the peripheral circulation, the IGFBP2 amount is second to IGFBP3 [14]. IGF-1 is a stimulus synthesized of IGFBP2, and growth hormone $(\mathrm{GH})$ is an inhibitor [36]. There is some controversy about the effects of IGFBP2 on health. On the one hand, there is tight correlation between the low concentration of serum IGFBP2 and the high degree of obesity and insulin resistance [37]. On the other hand, in the elderly, low serum IGFBP-2 prompt good physical function, high IGFBP-2 concentration suggests that the disability, poor body function, weak muscle strength and low bone density, and smaller lean and fat mass [38]. Alpha-2-macroglobulin ( $\alpha 2 \mathrm{M})$ is the only protein binding with IGFBP2. Recent studies have found that $\alpha 2 \mathrm{M}$ and IGFBP2 can form complex, but the physiological function of this phenomenon is not clear [39].

\section{IBFBP3}

By cDNA microarray technology, Kim et al. found that IGFBP3 increased in dermal fibroblasts in the aged human [40]. The mRNA and protein of IGFBP3 increase in human umbilical vein endothelial cells (HUVECs) in the aged human. In young HUVECs, decreasing the expression of IGFBP3 can rescue growth arrest induced by P53 overexpression. In young cells, up-regulating IGFBP3 or stimulated by IGFBP3 continuously could accelerate cell senescence. In addition, IGFBP3 expressed in liver and serum increased with aging in rats, and the energy restriction could reduce IGFBP3 protein expression which indicated that IGFBP3 played an important role in the HUVECs senescence and body aging. Elzi et al. found that the activity of IGFBP3 inducing aging is inhibited by tissue-type plasminogen activator which can mediate IGFBP3 hydrolysis in human breast cancer cells, and the effect can be offset by another intermediary secretion plasmin plasminogen activator inhibitor (plasminogen activator inhibitor 1, 
PAI-1). This shows that IGFBP3 is important downstream targets induced by PAI-1 senescence [41].

\section{IGFBP5}

Kim's another study found that knockdown of IGFBP5 can cause a series of phenotypes associated with aging. Knockdown of P53 can ameliorate premature senility mediated by IGFBP 5 increasing. In addition, atherosclerotic plaque has a strong positive staining for P53.This indicates that IGFBP5 has an important role in the regulation of cell aging and aging associated with vascular diseases through a p53 dependent pathway [42]. Kojima's study shows that STAT3-IGFBP5 axis is an important part in the mechanism which IL-6/gp130 induced human fibroblast senescence [43].

\section{IGFBP4 and IGFBP7}

Severino's studies suggested that IGFBP4 and IGFBP7 were important components inducing senescence in stem cells mesenchymal (MSCs). Stimulating MSCs with rIGFBP4/7 could accelerate cell senescence and induce apoptosis [35].

There was a debate about IGFBP7 in tumor senescence. By genomewide RNA-interference-mediated screens in mice, Wajapeyee et al. identified IGFBP7 is one of 17 genes required in activating BRAF oncogene (BRAFV600E) inhibiting proliferation of melanin tumor cells. The expression of BRAFV600E in primary cells caused synthesis and secretion of IGFBP7, which inhibited BRAF-MEK-ERK signal and induced cell senescence and apoptosis by autocrine or paracrine [44]. Scurr et al. found that BRAF signal cannot induce IGFBP7 expression in the melanin cells and fibroblasts, also not to induce the expression of IGFBP7' interaction protein (BNIP3L, smarcb1 and PEA15), and it was found there is no correlation between BRAF mutation and expression of IGFBP7 in 22 class of melanoma cell lines, 90 melanoma and 46 benign nevi. In addition, the use of slow virus silencing IGFBP7 experiments found that BRAF inducing melanoma cells and fibroblast cell aging don't depend on IGFBP7 [45]. Therefore, it is considered that the IGFBP7 is not necessary in the aging of the cells induced by BRAFV600E. Articles have been published, Wajapeyee et al. supplied the data that BRAFV600E transcription induced IGFBP7 expression in melanoma and IGFBP7 was indispensable in BRAFV600E mediating aging. In summary, IGFBP7 is a tumor suppressor protein in melanoma [46].

\section{IGF System in Age Related Diseases}

\section{IGF-1 in cardiovascular disease and vascular senescence}

Cardiovascular disease includes heart failure, myocardial infarction, stroke, hypertension and its complications and aortic aneurysm, peripheral artery disease, which are important factor causing the incidence and death of the elderly. Heart and tissue blood supply deficiency along with age is an important reason for the aging of human body [47]. Vascular aging is a process which the functions of endothelial cells (ECs) and vascular smooth muscle cells change by oxidation, inflammation, cell senescence, and epigenetic modification, resulting in the increase incidences of atherosclerosis and other diseases. Decrease IGF-1 along with age was closely related to changes in molecular, cellular and functional of the aging of the cardiovascular system $[48,49]$. Recent studies have found a negative correlation between IGF-1 in the circulation and cardiovascular disease [50,51]. The results showed that elderly people with low levels of IGF-1 had a higher risk of ischemic stroke and congestive heart failure, and poor prognosis in recovery period of acute myocardial infarction [52-54]. In most observational studies, GH deficiency and decreased level of IGF-1 increased the risk of cardiovascular disease such as atherosclerosis and other cardiovascular diseases in adults [55]. Laughlin and colleagues monitored 1185 patients for 10 years, and concluded that circulating IGF-1 levels were predictive of ischemic heart disease [49].

R Granata's studies suggest that IGF-1 has an anti-atherosclerosis effect by anti-inflammation and repair mechanisms [56]. Higashi et al. reported that IGF-1 enhanced the antioxidant activity and activity of endothelial cells (ECs) by down regulating the expression of glutathione peroxidase 1 [57]. The effect of GH/IGF-1 axis on the cardiovascular system is considered as a potential mechanism for the protection of micro vessel and cardiac protection in aging.

\section{IGF-1 in osteoporosis and vertebral aging}

Aging is accompanied by a decrease in bone structure and function, which significantly increases the risk of osteoporosis and fracture in elderly patients. Changes related with aging in bone health are the result of bone formation changing to bone resorption [58]. Some hormones, including IGF-1 and steroid hormones, are important for bone health and osteoblast activity. Knockdown of IGF-1R in osteoblasts leads to a reduction in adult bone size and adult bone mineral density $[59,60]$. Similarly, specific deletion of the IGF-1 product in the liver leads to a decrease in adult femoral length and bone mineral density $[61,62]$. In addition, a large number of clinical trials have shown that lowering the IGF-1 levels in circulation increases the risk of osteoporosis $[63,64]$. The studies clearly stressed the importance of IGF-1 in normal bone development, but the effect on vertebral structure and function of changes related with age induced by reduction of circulating IGF-1 remains unclear.

Interestingly, high levels of IGF do not always mean to increase bone health. Such as the early knockout of acid labile subunit (ALS) in circulation which is an important stabilizing protein of IGF-1 could reduce $60 \% \sim 75 \%$ of IGF-1, but decrease cortical thickness in aged male rats [65]. This showed early or long-term IGF-1 deficiency promoted aging of long bones. In contrast, a recent study found that a decrease of IGF-1 in circulation in the adult resulted in a decrease in the cortical and cancellous bone thickness in the aging process [66]. Therefore, the different results indicate that IGF-1 deletions may depend on the different stage of life. Interestingly, in female rats, absence of IGF-1 lead vertebrae volume fraction to increase $67 \%$, and the corresponding increase in density. Those suggest that IGF-1 regulates the aging depending on sex and time specific [67].

\section{Prospect}

The components of IGF system have a close relationship with cell senescence, signaling pathways in aging, aging related diseases. IGF-1 and IGFBPs interact with aging related molecules such as p53, GH, PAI-1 etc. in cell senescence. These molecules participate in a variety of signal transduction pathways, such as insulin/IGF-1 signal, Raf/Mek/ ErkRas/ and PI3K signaling pathway, mTOR signaling pathway, which lead to the aging of cells and the body. At present, there are still a lot of controversies in the study of different cells and tissues, and the molecules related with aging and pathways are not complete. Therefore, the molecular mechanism of the effect of IGF system on aging still needs further research. 
Page 4 of 5

\section{Financial Support}

This study is funded by a National Natural Science Foundation of China (No. 81401160) and National Basic Research Program of China (973 Program) (No. 2013CB530800).

\section{References}

1. Berryman DE, Christiansen JS, Johannsson G, Thorner MO, Kopchick JJ (2008) Role of the GH/IGF-1 axis in lifespan and healthspan: lessons from animal models. Growth Horm IGF Res 18: 455-471.

2. Paradis S, Ruvkun G (1998) Caenorhabditis elegans Akt/PKB transduces insulin receptor-like signals from AGE-1 PI3 kinase to the DAF-16 transcription factor. Genes Dev 12: 2488-2498.

3. Kenyon C, Chang J, Gensch E, Rudner A, Tabtiang R (1993) A C. elegans mutant that lives twice as long as wild type. Nature 366: 461-464.

4. Johnson TE (1990) Increased life-span of age-1 mutants in Caenorhabditis elegans and lower Gompertz rate of aging. Science 249: 908-912.

5. Carter CS, Ramsey MM, Sonntag WE (2002) A critical analysis of the role of growth hormone and IGF-1 in aging and lifespan. Trends Genet 18: 295-301.

6. Kenyon C (2001) A conserved regulatory system for aging. Cell 105: 165-168.

7. Clancy DJ, Gems D, Harshman LG, Oldham S, Stocker H, et al. (2001) Extension of life-span by loss of CHICO, a Drosophila insulin receptor substrate protein. Science 292: 104-106.

8. Fabrizio P, Pozza F, Pletcher SD, Gendron CM, Longo VD (2001) Regulation of longevity and stress resistance by Sch9 in yeast. Science 292: 288-290.

9. Minchenko DO, Kharkova AP, Tsymbal DO, Karbovskyi LL, Minchenko $\mathrm{OH}$ (2015) IRE1 inhibition affects the expression of insulin-like growth factor binding protein genes and modifies its sensitivity to glucose deprivation in U87 glioma cells. Endocr Regul 49: 185-197.

10. Rupp C, Scherzer M, Rudisch A, Unger C, Haslinger C, et al. (2015) IGFBP7, a novel tumor stroma marker, with growth-promoting effects in colon cancer through a paracrine tumor-stroma interaction. Oncogene 34: 815-825.

11. Zhu S, Xu F, Zhang J, Ruan W, Lai M (2014) Insulin-like growth factor binding protein-related protein 1 and cancer. Clin Chim Acta 431: 23-32.

12. Rinderknecht E, Humbel RE (1978) The amino acid sequence of human insulin-like growth factor I and its structural homology with proinsulin. J Biol Chem 253: 2769-2776.

13. Blundell TL, Bedarkar S, Humbel RE (1983) Tertiary structures, receptor binding, and antigenicity of insulinlike growth factors. Fed Proc 42: 2592-2597.

14. Firth SM, Baxter RC (2002) Cellular actions of the insulin-like growth factor binding proteins. Endocr Rev 23: 824-854.

15. Roberts CT Jr, Lasky SR, Lowe WL Jr, Seaman WT, LeRoith D (1987) Molecular cloning of rat insulin-like growth factor I complementary deoxyribonucleic acids: differential messenger ribonucleic acid processing and regulation by growth hormone in extrahepatic tissues. Mol Endocrinol 1: 243-248.

16. Han VK, Lund PK, Lee DC, D'Ercole AJ (1988) Expression of somatomedin/insulin-like growth factor messenger ribonucleic acids in the human fetus: identification, characterization, and tissue distribution. J Clin Endocrinol Metab 66: 422-429.

17. Lowe WL Jr, Lasky SR, LeRoith D, Roberts CT Jr (1988) Distribution and regulation of rat insulin-like growth factor I messenger ribonucleic acids encoding alternative carboxyterminal E-peptides: evidence for differential processing and regulation in liver. Mol Endocrinol 2: 528-535.

18. LeRoith D, Werner H, Beitner-Johnson D, Roberts CT Jr (1995) Molecular and cellular aspects of the insulin-like growth factor I receptor. Endocr Rev 16: 143-163.
19. Stewart CE, Rotwein P (1996) Growth, differentiation, and survival: multiple physiological functions for insulin-like growth factors. Physiol Rev 76: 1005-1026.

20. Jones JI, Clemmons DR (1995) Insulin-like growth factors and their binding proteins: biological actions. Endocr Rev 16: 3-34.

21. Degrauwe N, Suva ML, Janiszewska M, Riggi N, Stamenkovic I (2016) IMPs: an RNA-binding protein family that provides a link between stem cell maintenance in normal development and cancer. Genes Dev 30: 2459-2474.

22. Tatulian SA (2015) Structural Dynamics of Insulin Receptor and Transmembrane Signaling. Biochemistry 54: 5523-5532.

23. Sehat B, Andersson S, Girnita L, Larsson O (2008) Identification of c-Cbl as a new ligase for insulin-like growth factor-I receptor with distinct roles from Mdm2 in receptor ubiquitination and endocytosis. Cancer Res 68: 5669-5677.

24. Steele-Perkins G, Turner J, Edman JC, Hari J, Pierce SB, et al. (1988) Expression and characterization of a functional human insulin-like growth factor I receptor. J Biol Chem 263: 11486-11492.

25. Frattali AL, Pessin JE (1993) Relationship between alpha subunit ligand occupancy and beta subunit autophosphorylation in insulin/insulin-like growth factor-1 hybrid receptors. J Biol Chem 268: 7393-7400.

26. Berthe ML, Esslimani Sahla M, Roger P, Gleizes M, Lemamy GJ, et al. (2003) Mannose-6-phosphate/insulin-like growth factor-II receptor expression levels during the progression from normal human mammary tissue to invasive breast carcinomas. Eur J Cancer 39: 635-642.

27. Morgan DO, Edman JC, Standring DN, Fried VA, Smith MC, et al. (1987) Insulin-like growth factor II receptor as a multifunctional binding protein. Nature 329: 301-307.

28. Braulke T (1999) Type-2 IGF receptor: a multi-ligand binding protein. Horm Metab Res 31: 242-246.

29. Zaina S, Squire S (1998) The soluble type 2 insulin-like growth factor (IGF-II) receptor reduces organ size by IGF-II-mediated and IGF-IIindependent mechanisms. J Biol Chem 273: 28610-28616.

30. Costello M, Baxter RC, Scott CD (1999) Regulation of soluble insulin-like growth factor II/mannose 6-phosphate receptor in human serum: measurement by enzyme-linked immunosorbent assay. J Clin Endocrinol Metab 84: 611-617.

31. Chrysis D, Calikoglu AS, Ye P, D'Ercole AJ (2001) Insulin-like growth factor-I overexpression attenuates cerebellar apoptosis by altering the expression of Bcl family proteins in a developmentally specific manner. J Neurosci 21: 1481-1489.

32. Hwa V, Oh Y, Rosenfeld RG (1999) The insulin-like growth factorbinding protein (IGFBP) superfamily. Endocr Rev 20: 761-787.

33. Tran D, Bergholz J, Zhang H, He H, Wang Y, et al. (2014) Insulin-like growth factor-1 regulates the SIRT1-p53 pathway in cellular senescence. Aging Cell 13: 669-678.

34. Selman C, Lingard S, Choudhury AI, Batterham RL, Claret M, et al. (2008) Evidence for lifespan extension and delayed age-related biomarkers in insulin receptor substrate 1 null mice. FASEB J 22: 807-818.

35. Severino V, Alessio N, Farina A, Sandomenico A, Cipollaro M, et al. (2013) Insulin-like growth factor binding proteins 4 and 7 released by senescent cells promote premature senescence in mesenchymal stem cells. Cell Death Dis 4: e911.

36. Hoeflich A, Reisinger R, Lahm H, Kiess W, Blum WF, et al. (2001) Insulin-like growth factor-binding protein 2 in tumorigenesis: protector or promoter? Cancer Res 61: 8601-8610.

37. Wheatcroft SB, Kearney MT, Shah AM, Ezzat VA, Miell JR, et al. (2007) IGF-binding protein-2 protects against the development of obesity and insulin resistance. Diabetes 56: 285-294.

38. Hu D, Pawlikowska L, Kanaya A, Hsueh WC, Colbert L, et al. (2009) Serum insulin-like growth factor-1 binding proteins 1 and 2 and mortality in older adults: The Health, Aging, and Body Composition Study. J Am Geriatr Soc 57: 1213-1218. 
Page 5 of 5

39. Sunderic M, Miljus G, Nedic O (2013) Interaction of insulin-like growth factor-binding protein 2 with alpha2-macroglobulin in the circulation. Protein J 32: 138-142.

40. Kim KS, Kim MS, Seu YB, Chung HY, Kim JH, et al. (2007) Regulation of replicative senescence by insulin-like growth factor-binding protein 3 in human umbilical vein endothelial cells. Aging Cell 6: 535-545.

41. Elzi DJ, Lai Y, Song M, Hakala K, Weintraub ST, et al. (2012) Plasminogen activator inhibitor 1--insulin-like growth factor binding protein 3 cascade regulates stress-induced senescence. Proc Natl Acad Sci USA 109: 12052-12057.

42. Kim KS, Seu YB, Baek SH, Kim MJ, Kim KJ, et al. (2007) Induction of cellular senescence by insulin-like growth factor binding protein-5 through a p53-dependent mechanism. Mol Biol Cell 18: 4543-4552.

43. Kojima H, Kunimoto H, Inoue T, Nakajima K (2012) The STAT3-IGFBP5 axis is critical for IL-6/gp130-induced premature senescence in human fibroblasts. Cell Cycle 11: 730-739.

44. Wajapeyee N, Serra RW, Zhu X, Mahalingam M, Green MR (2008) Oncogenic BRAF induces senescence and apoptosis through pathways mediated by the secreted protein IGFBP7. Cell 132: 363-374.

45. Scurr LL, Pupo GM, Becker TM, Lai K, Schrama D, et al. (2010) IGFBP7 is not required for B-RAF-induced melanocyte senescence. Cell 141: 717-727.

46. Wajapeyee N, Serra RW, Zhu X, Mahalingam M, Green MR (2010) Role for IGFBP7 in senescence induction by BRAF. Cell 141: 746-747.

47. Ungvari Z, Csiszar A (2012) The emerging role of IGF-1 deficiency in cardiovascular aging: recent advances. J Gerontol A Biol Sci Med Sci 67: 599-610.

48. Hausenloy DJ, Yellon DM (2013) Myocardial ischemia-reperfusion injury: a neglected therapeutic target. J Clin Invest 123: 92-100.

49. Laughlin GA, Barrett-Connor E, Criqui MH, Kritz-Silverstein D (2004) The prospective association of serum insulin-like growth factor I (IGF-I) and IGF-binding protein-1 levels with all cause and cardiovascular disease mortality in older adults: the Rancho Bernardo Study. J Clin Endocrinol Metab 89: 114-120.

50. Berryman DE, Glad CA, List EO, Johannsson G (2013) The GH/IGF-1 axis in obesity: pathophysiology and therapeutic considerations. Nat Rev Endocrinol 9: 346-356.

51. Juul A, Scheike T, Davidsen M, Gyllenborg J, Jorgensen T (2002) Low serum insulin-like growth factor $\mathrm{I}$ is associated with increased risk of ischemic heart disease: a population-based case-control study. Circulation 106: 939-944.

52. Troncoso R, Ibarra C, Vicencio JM, Jaimovich E, Lavandero S (2014) New insights into IGF-1 signaling in the heart. Trends Endocrinol Metab 25: 128-137.

53. Vasan RS, Sullivan LM, D'Agostino RB, Roubenoff R, Harris T, et al. (2003) Serum insulin-like growth factor I and risk for heart failure in elderly individuals without a previous myocardial infarction: the Framingham Heart Study. Ann Intern Med 139: 642-648.

54. Conti E, Andreotti F, Sciahbasi A, Riccardi P, Marra G, et al. (2001) Markedly reduced insulin-like growth factor- 1 in the acute phase of myocardial infarction. J Am Coll Cardiol 38: 26-32.

55. Palmeiro CR, Anand R, Dardi IK, Balasubramaniyam N, Schwarcz MD, (2012) Growth hormone and the cardiovascular system. Cardiol Rev 20: 197-207.

56. Penna C, Settanni F, Tullio F, Trovato L, Pagliaro P, et al. (2013) GHreleasing hormone induces cardioprotection in isolated male rat heart via activation of RISK and SAFE pathways. Endocrinology 154: 1624-1635.

57. Higashi Y, Pandey A, Goodwin B, Delafontaine P (2013) Insulin-like growth factor-1 regulates glutathione peroxidase expression and activity in vascular endothelial cells: Implications for atheroprotective actions of insulin-like growth factor-1. Biochim Biophys Acta 1832: 391-399.

58. Burge R, Dawson-Hughes B, Solomon DH, Wong JB, King A, (2007) Incidence and economic burden of osteoporosis-related fractures in the United States, 2005-2025. J Bone Miner Res 22: 465-475.

59. Zhang M, Xuan S, Bouxsein ML, von Stechow D, Akeno N, et al. (2002) Osteoblast-specific knockout of the insulin-like growth factor (IGF) receptor gene reveals an essential role of IGF signaling in bone matrix mineralization. J Biol Chem 277: 44005-44012.

60. Kubota T, Elalieh HZ, Saless N, Fong C, Wang Y, et al. (2013) Insulin-like growth factor-1 receptor in mature osteoblasts is required for periosteal bone formation induced by reloading. Acta Astronaut 92: 73-78.

61. Sjogren K, Sheng M, Moverare S, Liu JL, Wallenius K, et al. (2002) Effects of liver-derived insulin-like growth factor I on bone metabolism in mice. J Bone Miner Res 17: 1977-1987.

62. Courtland HW, Elis S, Wu Y, Sun H, Rosen CJ, et al. (2011) Serum IGF-1 affects skeletal acquisition in a temporal and compartment-specific manner. PLoS One 6: e14762.

63. Paccou J, Dewailly J, Cortet B (2012) Reduced levels of serum IGF-1 is related to the presence of osteoporotic fractures in male idiopathic osteoporosis. Joint Bone Spine 79: 78-82.

64. Zhao DD, Jiao PL, Yu JJ, Wang XJ, Zhao L, et al. (2016) Higher Serum Uric Acid Is Associated with Higher Bone Mineral Density in Chinese Men with Type 2 Diabetes Mellitus. Int J Endocrinol 2016: 2528956.

65. Courtland HW, Kennedy OD, Wu Y, Gao Y, Sun H, et al. (2013) Low levels of plasma IGF-1 inhibit intracortical bone remodeling during aging. Age (Dordr) 35: 1691-1703.

66. Gong Z, Kennedy O, Sun H, Wu Y, Williams GA, et al. (2014) Reductions in serum IGF-1 during aging impair health span. Aging Cell 2014, 13: 408-418.

67. Ashpole NM, Herron JC, Mitschelen MC, Farley JA, Logan S, et al. (2016) IGF-1 Regulates Vertebral Bone Aging Through Sex-Specific and TimeDependent Mechanisms. J Bone Miner Res 31: 443-454. 